\title{
Bacterial carbon flow in the Humboldt Current System off Chile
}

\author{
V. Alfredo Troncoso ${ }^{1}$, Giovanni Daneri ${ }^{2, *}$, L. Antonio Cuevas ${ }^{1}$, Bárbara Jacob ${ }^{2}$, \\ Paulina Montero ${ }^{2}$
}

\author{
${ }^{1}$ Departamento de Oceanografía, Universidad de Concepción, PO 160-C, Concepción, Chile \\ ${ }^{2}$ Centro de Ciencias y Ecología Aplicada (CEA), Universidad del Mar, Carmen 446, Valparaíso, Chile
}

\begin{abstract}
During this study, bacterial secondary production (BSP) was measured at 3 coastal upwelling sites (Antofagasta, latitude $23^{\circ} \mathrm{S}$; Coquimbo, latitude $30^{\circ} \mathrm{S}$; and Concepción, latitude $36^{\circ} \mathrm{S}$ ) within the Humboldt Current System (HCS) off Chile. The data show that bacteria are an important component of pelagic food webs in these areas. The coastal area of Antofagasta had the highest level of bacterial activity $\left(1722 \pm 1362 \mathrm{mg} \mathrm{C} \mathrm{m}^{-2} \mathrm{~d}^{-1}\right)$, the coastal area of Coquimbo the values $(77 \pm 56 \mathrm{mgC}$ $\mathrm{m}^{-2} \mathrm{~d}^{-1}$ ). The low levels observed in Coquimbo are in agreement with the observation that Coquimbo is an oligotrophic area of persistent upwelling that persistently shows low primay production (PP) values. A BSP value of ca. $5000 \mathrm{mgC} \mathrm{m}^{-2} \mathrm{~d}^{-1}$ measured during this study in the coastal area of Antofagasta constitutes the highest BSP value ever reported in the literature. In the 3 upwelling areas sampled a significant proportion of the PP was utilised by bacteria (ca. 63 to $96 \%$ in Antofagasta, 16 to $34 \%$ in Coquimbo and 10 to $24 \%$ in Concepción). A strong correlation between BSP and PP was found during this study $\left(\mathrm{r}^{2}=0.57, \mathrm{n}=51\right)$, reflecting a tight coupling between carbon synthesis and bacterial consumption. The high correlation between PP and BSP, coupled with the lack of correlation between temperature and BSP $\left(\mathrm{r}^{2}=0.0, \mathrm{n}=420\right)$, indicates that in the HCS off Chile substrate availability seems to be more important than temperature in limiting bacterial activity and abundance.
\end{abstract}

KEY WORDS: Bacterioplankton · Biomass · Production $\cdot$ Humboldt Current $\cdot$ Upwelling

\section{INTRODUCTION}

The Humboldt Current System (HCS) of Chile is an eastern boundary current system typified by the occurrence of coastal upwelling, the presence of a shallow nutrient-rich oxygen-depleted subsurface water mass, and interannual variations associated with El Niño events. The upwelling of subsurface waters triggers a vigorous exchange of $\mathrm{CO}_{2}$ and heat. Subsequently, water stabilisation, due to lateral mixing and solar surface heating, stimulates the growth of phytoplankton. The primary production levels are among the highest reported in the literature (Daneri et al. 2000).

The high fish production in upwelling systems has been primarily associated with recurrent upwelling pulses and with the predominance of short, thermodynamically efficient food chains (Ryther 1969, Ryther

*Corresponding author. Email: gdaneri@udelmar.cl et al. 1971). This early view, based on a simplified structure and functioning of the food chain in upwelling systems, is now under revision. Central to this has been a re-evaluation of the importance of bacteria in a variety of marine environments (McManus \& Peterson 1988). Bacterioplankton constitutes an important fraction of the total carbon biomass in pelagic ecosystems. In oligotrophic waters bacterial biomass can be 2 to 3 times more abundant than phytoplankton (Cho \& Azam 1990), and in meso- and eutrophic environments 0.5 to 2 times greater (Azam et al. 1983). Bacteria are an important pelagic mineralizer of organic matter. It has been reported that, depending on environmental conditions, bacterial secondary production (BSP), as a percentage of primary production (PP), can fluctuate between 2 and $1101 \%$ (Andrews \& Williams 1971, Sieburth et al. 1977, Hagström et al. 1979, Fuhrman \& 
Azam 1982, see also references in Table 1). This may represent an underestimation, as most of the estimates of BSP/PP \% do not take into consideration that bacterial activity continues at night (McManus \& Peterson 1988).

Bacterial production and abundance in coastal upwelling ecosystems is similar to that reported for other coastal environments and seems to be closely coupled to upwelling cycles (Field et al. 1980, Zimmermann et al. 1980, Gocke et al. 1983, Rheinheimer \& Schmaljohann 1983, Hanson et al. 1986, McManus \& Peterson 1988). In the Benguela upwelling system, BSP has been shown to increase a few days after the peak of PP (Painting et al. 1993). A similar decoupling between PP and BSP has been reported by McManus \& Peterson (1988) for the Concepción upwelling ecosystem in the HCS off Chile. McManus \& Peterson (1988) showed that PP was lowest during periods of active upwelling and highest during subsequent periods of calm or light northerly winds, with BSP showing the greatest increase 1 or $2 \mathrm{~d}$ after the peak in phytoplankton production.

Watson (1978) estimated ocean global production to be 25 to $75 \mathrm{~g} \mathrm{C} \mathrm{m}^{-2} \mathrm{yr}^{-1}$ for open ocean areas, $100 \mathrm{gC}$ $\mathrm{m}^{-2} \mathrm{yr}^{-1}$ for coastal areas and up to $300 \mathrm{~g} \mathrm{C} \mathrm{m}^{-2} \mathrm{yr}^{-1}$ for upwelling ecosystems. Higher values of $1 \mathrm{~kg} \mathrm{C} \mathrm{m}^{-2} \mathrm{yr}^{-1}$ and $0.93 \mathrm{kgC} \mathrm{m}^{-2} \mathrm{yr}^{-1}$ have been estimated for the Peruvian upwelling (Walsh 1981) and for the southern Chilean upwelling (Daneri et al. 2000), respectively. While the PP in oligotrophic areas depends mostly on regenerated ( $\mathrm{NH}_{3}$-based) nitrogen in upwelling or highly productive coastal areas, PP is mainly supported by the injection of $\mathrm{NO}_{3}$ into the photic layer. New production in highly productive ecosystems is typically in the order of 50 to $70 \%$ of the total production, indicating the dependence of primary production on nutrients advected from subsurface waters. Although in these productive areas, dependence of PP on epipelagically produced nutrients is not as crucial as in oligotrophic areas, absolute rates of nutrient regeneration by the heterotrophic community are not insignificant (C. Morales pers. comm.). It is now accepted that a high proportion of the organic carbon produced by the phytoplankton may flow through the bacteria in a variety of marine environments, including upwelling areas. A significant amount of carbon flowing through the bacterioplankton may imply that the carrying capacity for fishes in upwelling ecosystems is considerably less than that which might be anticipated for a simple herbivoredominated food chain (Newell \& Turley 1987).

Table 1. Summary of primary production (PP), bacterial secondary production (BSP) and bacterial abundance (BA), BSP/PP\% reported in the literature for contrasting marine ecosystems. Spaces: no data

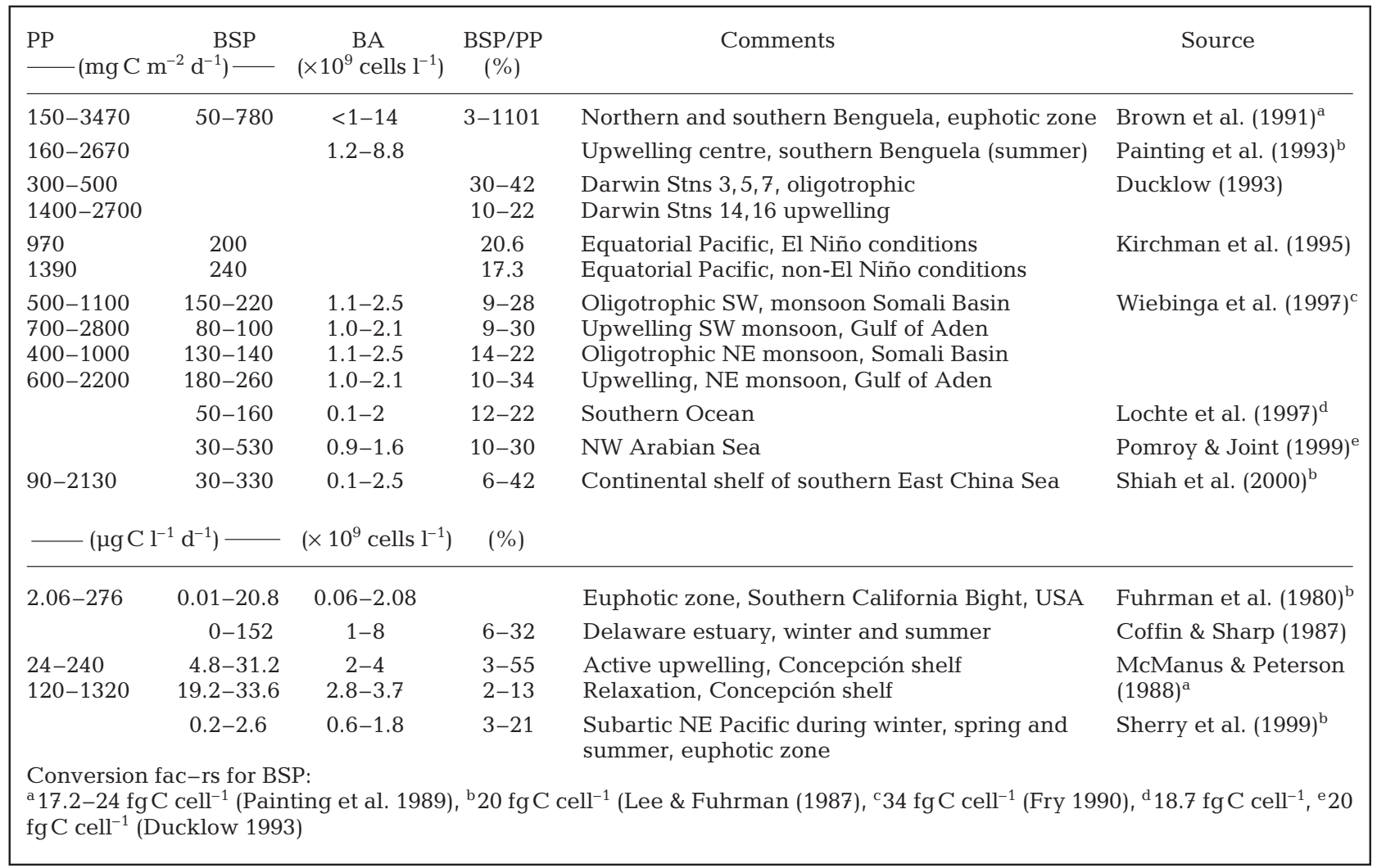


In this paper, the relationship between bacterial production and abundance and phytoplankton biomass and production in 3 upwelling ecosystems in the HCS off Chile (Antofagasta, $23^{\circ} \mathrm{S}$; Coquimbo, $30^{\circ} \mathrm{S}$; Concepción, $36^{\circ} \mathrm{S}$ ) and adjacent oceanic areas is examined. Based on estimated bacterial growth yields, the total carbon flux through the bacteria was assessed under a range of environmental conditions. The large amount of data allowed, for the first time, a comprehensive understanding of the role of bacterioplankton in the HCS of Chile.

\section{MATERIALS AND METHODS}

Cruises and stations. The study was carried out at 3 coastal upwelling sites in the HCS off Chile. Sampling took place off Antofagasta $\left(23^{\circ} \mathrm{S}\right)$, during January (summer) and July (winter) 1997 on board the RV 'Abate Molina' as part of the Sectorial Antofagasta (CONICYT-
Chile) research programme. The Antofagasta stations were sampled within a grid bounded by $22^{\circ} 40^{\prime}$ to $24^{\circ} 00^{\prime} \mathrm{S}$ and $70^{\circ} 30^{\prime} \mathrm{W}$ to $71^{\circ} 52^{\prime} \mathrm{W}$. During July 1997 stations were sampled in a transect from the coast to 200 miles offshore (Fig. 1). Sampling at Coquimbo $\left(30^{\circ} \mathrm{S}\right)$ was undertaken as part of a series of short research cruises of the JGOFS-Chile program on board the RV 'Abate Molina' and the AGOR 'Vidal Gormaz'. The JGOFSChile (Coquimbo area) results are from a fixed transect from the coast to offshore, running from the Coquimbo coastal station (COSMOS) $\left(30^{\circ} 20^{\prime} 90^{\prime \prime} \mathrm{S}, 71^{\circ} 47^{\prime} 40^{\prime \prime} \mathrm{W}\right)$ to

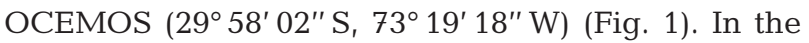
shelf upwelling area of Concepción $\left(36^{\circ} \mathrm{S}\right), 2$ multidisciplinary intensive research cruises (MIRC I and MIRC II) took place in October (spring) 1998 and July (winter) 1999 as part of the FONDAP-Humboldt research program. Sampling took place in a quasi-synoptic M-type grid during both cruises along a coast-to-offshore transect starting 5 nautical miles (n miles) from the coast and ending $200 \mathrm{n}$ miles offshore (Fig. 1).

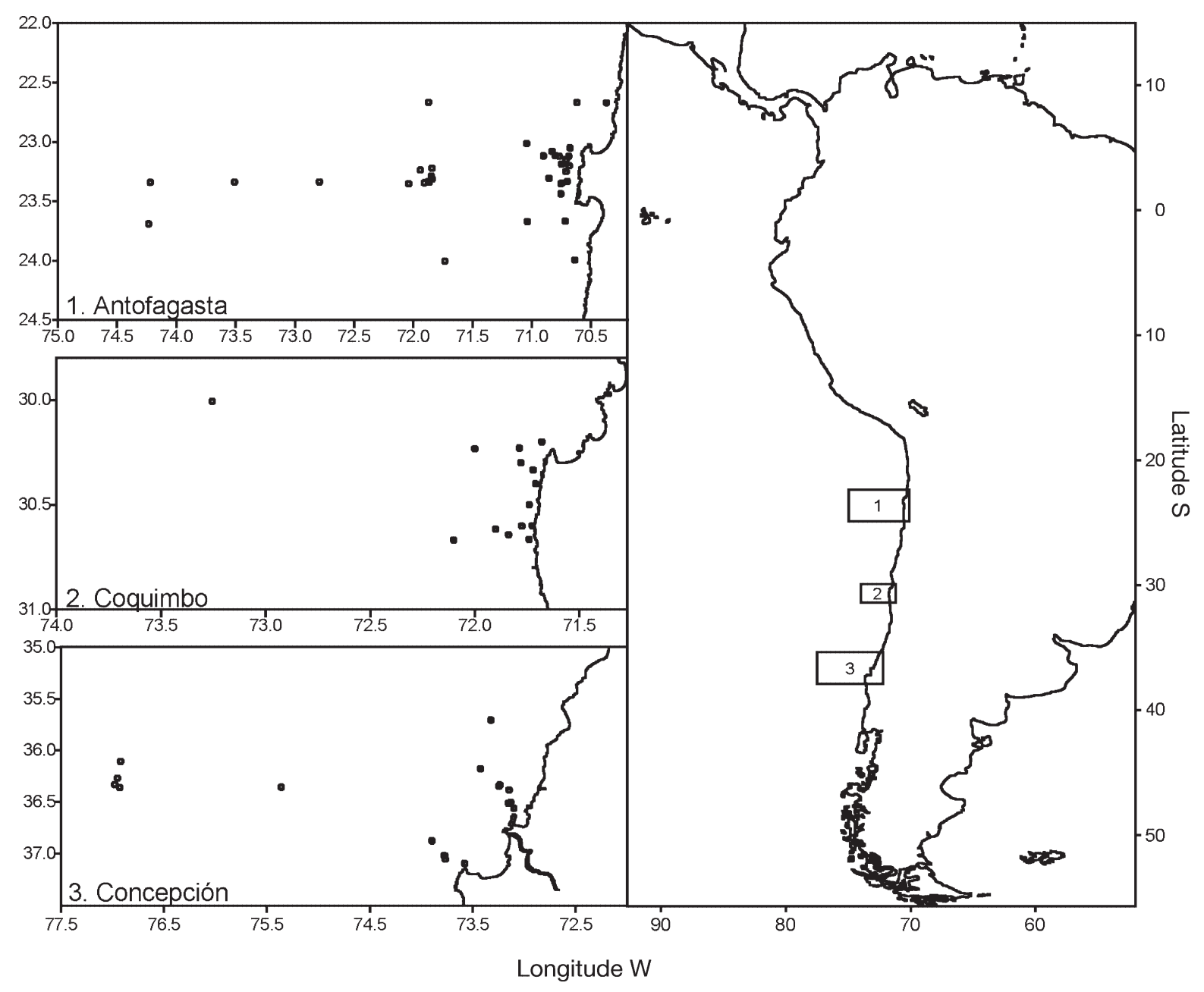

Fig. 1. Area sampled. (1) Antofagasta upwelling, (2) Coquimbo upwelling, (3) Concepción upwelling 
In this study, the terms 'inshore' or 'coastal' refer to areas within $40 \mathrm{n}$ miles of the coast, while 'offshore' or 'oceanic' refer to stations sampled at distances $>100$ miles from the coast for Coquimbo and Concepción and >60 miles for Antofagasta.

The highly dynamic nature of the HCS allowed us to sample upwelling areas under contrasting oceanographic conditions (Table 2). The January cruise to the Antofagasta upwelling system took place during an unusual period of low wind stress which preceded the 1997-98 El Niño event. This resulted in a weakening of upwelling and a decrease in the productivity of the system (Daneri et al. 2000). The second cruise to the Antofagasta region took place while the area was being affected by the 1997-98 El Niño event, one of the strongest ever recorded. The spring (upwelling season) and winter (non-upwelling season) cruises to the Concepción shelf area took place in the period after the 1997-98 El Niño under oceanographic conditions associated with La Niña. The Coquimbo area was sampled during oceanographic periods regarded as normal. Coquimbo, however, is an area of persistent upwelling but consistently low water productivity (Daneri et al. 2000) (Table 2).

Sample collection and hydrographic measurements. During the cruises on board the RV 'Abate Molina' and the AGOR 'Vidal Gormaz', water samples for primary production (PP), bacterial secondary production (BSP), and chlorophyll a (chl a) were obtained within the photic zone using Niskin bottles attached to a CTD rosette sampler. Samples for bacterial abundance (BA) and bacterial biomass (BB) were collected only during the Sectorial Antofagasta and MIRC I and MIRC II cruises to the area of Concepción. Data on basic water-column structure was obtained from continuous CTD records using a Neil Brown (MK III) instrument equipped with oxygen sensors, in vivo fluorescence Sea-Tech (FL 3000), and a scalar (photosynthetically active radiation) PAR sensor (Biospherical Instrument, Model QSP-200L). The General Oceanic rosette sampler was equipped with 12 Niskin bottles of 5 l capacity ('Abate Molina' cruise), and a Sea-bird CTD installed in a General Oceanic rosette sampler equipped with 24 Niskin bottles of 1.51 capacity in the (AGOR 'Vidal Gormaz' cruise).

Bacterial abundance. Discrete seawater samples from the euphotic zone were collected directly from Niskin bottles in sterile tubes (50 ml capacity, Costar 3252) and preserved in the dark with cold glutaraldehyde ( $2 \% \mathrm{~W} / \mathrm{V}$ final concentration). Bacterial counting was performed with epifluorescence microscopy following the methodology of Porter \& Feig (1980). Samples (2 to $5 \mathrm{ml}$ ) were stained with DAPI (4, 6-diamidine 2 -fenilindol, Sigma D-1388) to $72 \mu \mathrm{M}$ final concentration, and collected on black $25 \mathrm{~mm}$ polycarbonate filters (0.2 $\mu \mathrm{m}$ pore size; Millipore GTBP). Ten random fields and a total of at least 400 cells were counted at $1000 \times$ with a Zeiss-Axioskop epifluorescence microscope equipped with quartz optics.

Bacterial biomass and biovolume. Bacterial cellular carbon was estimated using the equation $\mathrm{C}(\mathrm{fg})=$ $90.06 \times V\left(\mu \mathrm{m}^{3}\right)^{0.59}$, where $V=$ bacterial volume (Simon \& Azam 1989, Riemann \& Bell 1990); 2 epifluorescence microscopy pictures were taken for each sample. The cell volume was determined by measuring the longest cell axis on enlarged microphotographs (12500×). Between 100 to 200 cells were measured. Care was taken to measure the size of the bacterial cell wall and not the fluorescent halo around the bacteria. The biovolume was calculated using the equation $V(\mu \mathrm{m})^{3}=$ $\left(d^{2} \times \pi / 4\right) \times(1-d)+\left(\pi \times d^{3} / 6\right)$, where $d=$ diameter and $l=$ length (Watson et al. 1977). Bacterial cell carbon was determined at 8 stations in the Antofagasta region (summer/winter). For the Concepción samples, bacterial cell carbon was determined at 1 coastal station during spring and 2 stations (coastal and oceanic) during winter. Significant differences between the summer (54 fgC) and winter (41 fgC) average cell-carbon amounts were found for Antofagasta (Mann-Whitney $U=131.5, \mathrm{p}<0.0001)$. In the spring cruise off Concep-

Table 2. Summary of research cruises and oceanographic conditions during present study

\begin{tabular}{|c|c|c|c|c|}
\hline Research programme & Vessel(s) & Date & Season & Conditions \\
\hline \multirow[t]{2}{*}{$\begin{array}{l}\text { Antofagasta } 23^{\circ} \mathrm{S} \\
\text { Sectorial }\end{array}$} & RV 'Abate Molina' & January 1997 & Summer & $\begin{array}{l}\text { Low wind stress; preconditions; 1997-98 } \\
\text { El Niño event }\end{array}$ \\
\hline & & July 1997 & Winter & 1997-98 El Niño event \\
\hline \multirow[t]{2}{*}{$\begin{array}{l}\text { Coquimbo } 30^{\circ} \mathrm{S} \\
\text { JGOFS-Chile }\end{array}$} & & $\begin{array}{c}1992,1993,1994 \\
1996,1997\end{array}$ & Summer & $\begin{array}{l}\text { Persistent upwelling but } \\
\text { low subsequent }\end{array}$ \\
\hline & AGOR 'Vidal Gormaz' & $1992,1995,1996$ & Winter & Water productivity \\
\hline \multirow[t]{2}{*}{$\begin{array}{l}\text { Concepción } 36^{\circ} \mathrm{S} \\
\text { FONDAP-Humboldt }\end{array}$} & RV 'Abate Molina' & October 1998 & Spring & $\begin{array}{l}\text { After the 1997-98 El Niño event; } \\
\text { upwelling season }\end{array}$ \\
\hline & & July 1999 & Winter & $\begin{array}{l}\text { Conditions associated with La Niña } \\
\text { event; non-upwelling season }\end{array}$ \\
\hline
\end{tabular}


ción (MIRC I), the average bacterial cell carbon was $27 \mathrm{fgC}$, while in the winter cruise (MIRC-II) the average was $22 \mathrm{fg} C$ at the coastal stations and $16 \mathrm{fg} C$ at the oceanic station (Mann-Whitney $U=2, \mathrm{p}<0.01$ ). Based on these results, we used values of 54 and $41 \mathrm{fgC}$ for the summer and winter cruises off Antofagasta, $27 \mathrm{fg} C$ for the spring in Concepción and 22 and $16 \mathrm{fg} \mathrm{C}$ for the coastal and oceanic stations in the winter cruise of Concepción, respectively. Water-column bacterial organic carbon (BOC) or biomass was estimated by multiplying bacterial cellular carbon by the water column bacterial abundance.

Bacterial secondary production (BSP). BSP was measured through the incorporation of [methyl- $\left.{ }^{3} \mathrm{H}\right]-$ thymidine to the DNA (Fuhrman \& Azam 1982, as modified by Wicks \& Robarts 1987). Discrete seawater samples were collected from the process study stations at 6 light depths from the surface to the $1 \%$ light depth for the simultaneous measurement of PP and BSP. Within $15 \mathrm{~min}$ of collection, $10 \mathrm{ml}$ from each depth sample was transferred to sterile tubes (Falcon 2051) of $15 \mathrm{ml}$ capacity ( 3 replicates and 1 blank). The blanks were poisoned with formalin (Merck) which had been sterilised using $45 \mathrm{~mm}$ Nuclepore $0.2 \mu \mathrm{m}$ pore-size polycarbonate filters. The samples were incubated with [methyl- $\left.{ }^{3} \mathrm{H}\right]$-thymidine $\left(50.1 \mathrm{Ci} \mathrm{mmol}^{-1}\right.$ specific activity, Sigma T-6527) to a final concentration of $10 \mathrm{nM}$ and maintained in the dark in a water bath provided with running surface seawater. In Antofagasta and Coquimbo the incubation time was $2 \mathrm{~h}_{\text {i }}$ in Concepción it was $1 \mathrm{~h}$. The incubation was stopped with the addition of $2.8 \mathrm{ml}$ of cold trichloroacetic acid (TCA) (p.a.) grade $(50 \% \mathrm{w} / \mathrm{v}, \mathrm{J}$. T. Baker) Following the procedure of Wicks \& Robarts (1987), after filtration $(<200 \mathrm{~mm} \mathrm{Hg})$ the sample was treated with $5 \mathrm{ml}$ of phenol-chloroform solution proanalysis (p.a.) grade $(50 \% \mathrm{w} / \mathrm{w})$ and re-filtered with $5 \mathrm{ml}$ of cold ethanol p.a. $(80 \% \mathrm{v} / \mathrm{v})$. After extraction of the DNA, the dried filters were kept cool until radioisotopic analysis. In the laboratory the vials were treated with ethyl acetate p.a. and $10 \mathrm{ml}$ Ecolite (+) (ICN). The incorporation of [methyl- $\left.{ }^{3} \mathrm{H}\right]$-thymidine was measured in dpm using a Packard (Model 1600 TR) liquid scintillation counter. The counting efficiency was calculated from the non-quenched standard of ${ }^{3} \mathrm{H}$-toluene. Moles of thymidine incorporated were transformed into cell production using a constant of $2 \times 10^{18}$ (Furhman \& Azam 1982). Simultaneous with the determination of BSP, samples from the same Niskin bottles were collected for bacterial abundance and biomass.

Chlorophyll a (chl a). Chl a was estimated using a Turner Designs fluorometer Model 10AU calibrated against pure chl a (Sigma) following the method of Holm-Hansen et al. (1965). Pigments were extracted on boardship in cold acetone $(90 \%)$ for $24 \mathrm{~h}$, and fluorescence was measured before and after acidification.

Primary production (oxygen and ${ }^{14} \mathrm{C}$ method). Primary production for the Antofagasta and Coquimbo upwelling ecosystem were estimated measuring the ${ }^{14} \mathrm{C}$ uptake by planktonic microalgae. Samples for PP experiments were collected at 10 stations using 51 PVC Niskin water-sampling bottles. Water samples were incubated in $100 \mathrm{ml}$ borosilicate glass for $4 \mathrm{~h}$ (mainly between 10:00 and 14:00 h). Temperature was regulated by running surface seawater over the incubation bottles. Sodium bicarbonate $\left(40 \mu \mathrm{Ci} \mathrm{NaH}{ }^{14} \mathrm{CO}_{3}\right)$ was added to each bottle. After incubation the bottle content was filtered, placed in $20 \mathrm{ml}$ scintillation vials and kept at $-15^{\circ} \mathrm{C}$ until reading (usually $15 \mathrm{~d}$ later). To remove excess inorganic carbon, filters were treated with $\mathrm{HCl}$ fumes for $4 \mathrm{~h}$. During the $2 \mathrm{MIRC}$ cruises to the Concepción upwelling area, PP was estimated from changes in dissolved oxygen concentrations during incubation of in vitro light and dark bottles. The ${ }^{14} \mathrm{C}$ procedure and results are fully described in Iriarte et al. (2000), the $\mathrm{O}_{2}$ method is fully described in Daneri et al. (2000).

\section{RESULTS}

\section{Antofagasta upwelling ecosystem}

\section{Summer (pre-El Niño)}

The Antofagasta upwelling ecosystem was visited during January 1997 under 'pre-El Niño' oceanographic conditions. Although the average PP measured at the inshore stations was relatively high $(4853 \pm 5261 \mathrm{mg} \mathrm{C}$ $\mathrm{m}^{-2} \mathrm{~d}^{-1}, \mathrm{n}=10$, range 632 to $14984 \mathrm{mgC} \mathrm{m}^{-2} \mathrm{~d}^{-1}$ ) (Table 3 ) it is possible that the anomalous drop in wind stress (under pre-El Niño conditions) did not allow the area to reach the full productivity potential expected for this time of the year. The average offshore PP was ca. 5 times lower than the PP inshore $\left(1076 \pm 405 \mathrm{mg} \mathrm{C} \mathrm{m}^{-2}\right.$ $\mathrm{d}^{-1}, \mathrm{n}=5$, range 745 to $1723 \mathrm{mg} \mathrm{C} \mathrm{m}^{-2} \mathrm{~d}^{-1}$ ). At the inshore stations, daily average BSP was $1722 \pm 1362 \mathrm{mgC}$ $\mathrm{m}^{-2} \mathrm{~d}^{-1}\left(\mathrm{n}=19\right.$, range 269 to $\left.4999 \mathrm{mg} \mathrm{C} \mathrm{m}^{-2} \mathrm{~d}^{-1}\right)$, while offshore it was almost half these values $(850 \pm 292 \mathrm{mgC}$ $\mathrm{m}^{-2} \mathrm{~d}^{-1}, \mathrm{n}=7$, range 469 to $1279 \mathrm{mg} \mathrm{C} \mathrm{m}^{-2} \mathrm{~d}^{-1}$ ). The average BA inshore was $17.5 \pm 7.2 \times 10^{9}$ cells m$^{-2}(\mathrm{n}=19$, range 5.2 to $27.8 \times 10^{9} \mathrm{cells} \mathrm{m}^{-2}$ ), while offshore it was $20.8 \pm 3.7 \times 10^{9}$ cells m$^{-2}(\mathrm{n}=7$, range 16.3 to $26.6 \times$ $10^{9}$ cells m$^{-2}$ ). The average BOC inshore was $941 \pm$ $386 \mathrm{mg} \mathrm{C} \mathrm{m}^{-2}$ ( $\mathrm{n}=19$, range 277 to $1497 \mathrm{mg} \mathrm{C} \mathrm{m}^{-2}$ ) while offshore it was $1114 \pm 198 \mathrm{mg} \mathrm{C} \mathrm{m}^{-2}(\mathrm{n}=7$, range 873 to $1428 \mathrm{mg} \mathrm{C} \mathrm{m}^{-2}$ ). Inshore the average BSP as percentage $\mathrm{PP}$ was $63 \pm 43 \%(\mathrm{n}=10$, range 20 to $145 \%)$ while offshore it was $83 \pm 9 \%(n=5$, range 74 to $99 \%)$. 
Table 3. Summary of integrated primary production (PP), bacterial secondary production (BSP), bacterial abundance (BA), bacterial organic carbon (BOC) and BSP/PP\% measured during this study. $\mathrm{n}=$ no. of samples

\begin{tabular}{|c|c|c|c|c|c|c|c|c|}
\hline \multicolumn{4}{|c|}{ Area and season } & $\begin{array}{c}\begin{array}{c}\mathrm{PP} \\
\left(\mathrm{mg} \mathrm{C} \mathrm{m}^{-2} \mathrm{~d}^{-1}\right)\end{array} \\
4853\end{array}$ & $\begin{array}{c}\begin{array}{c}\mathrm{BSP} \\
\left(\mathrm{mg} \mathrm{C} \mathrm{m}^{-2} \mathrm{~d}^{-1}\right)\end{array} \\
1722\end{array}$ & $\begin{array}{c}\begin{array}{c}\text { BA } \\
\left(10^{9} \text { cells m}^{-2}\right)\end{array} \\
17.5\end{array}$ & $\begin{array}{c}\begin{array}{c}\mathrm{BOC} \\
\left(\mathrm{mgC} \mathrm{m}^{-2}\right)\end{array} \\
941\end{array}$ & $\begin{array}{c}\begin{array}{c}\text { BSP/PP } \\
(\%)\end{array} \\
63\end{array}$ \\
\hline Antofagasta & Summer & Coast & $\begin{array}{l}\text { Avg } \\
\text { SD } \\
\text { Range } \\
n\end{array}$ & $\begin{array}{c}4853 \\
5261 \\
632-14984 \\
10\end{array}$ & $\begin{array}{c}1722 \\
1362 \\
296-4999 \\
19\end{array}$ & $\begin{array}{c}17.5 \\
7.2 \\
5.2-27.8 \\
19\end{array}$ & $\begin{array}{c}941 \\
386 \\
277-1497 \\
19\end{array}$ & $\begin{array}{c}63 \\
43 \\
20-145 \\
10\end{array}$ \\
\hline & & Ocean & $\begin{array}{l}\text { Avg } \\
\text { SD } \\
\text { Range } \\
n\end{array}$ & $\begin{array}{c}1076 \\
405 \\
745-1723 \\
5\end{array}$ & $\begin{array}{c}850 \\
292 \\
469-1279 \\
7\end{array}$ & $\begin{array}{c}20.8 \\
3.7 \\
16.3-26.6 \\
7\end{array}$ & $\begin{array}{c}1114 \\
198 \\
873-1428 \\
7\end{array}$ & $\begin{array}{c}83 \\
9 \\
74-99 \\
5\end{array}$ \\
\hline & Winter & Coast & $\begin{array}{l}\text { Avg } \\
\text { SD } \\
\text { Range } \\
\mathrm{n}\end{array}$ & $\begin{array}{c}1215 \\
1594 \\
23-3800 \\
7\end{array}$ & $\begin{array}{c}490 \\
178 \\
291-867 \\
16\end{array}$ & $\begin{array}{c}9.6 \\
4.4 \\
3.8-19.9 \\
16\end{array}$ & $\begin{array}{c}391 \\
178 \\
157-815 \\
16\end{array}$ & $\begin{array}{c}478 \\
726 \\
18-1811 \\
7\end{array}$ \\
\hline & & Ocean & $\begin{array}{l}\text { Avg } \\
\text { SD } \\
\text { Range } \\
n\end{array}$ & $\begin{array}{c}848 \\
628 \\
122-1799 \\
7\end{array}$ & $\begin{array}{c}450 \\
267 \\
243-1144 \\
13\end{array}$ & $\begin{array}{c}7.4 \\
2.6 \\
2.5-10.7 \\
13\end{array}$ & $\begin{array}{c}262 \\
136 \\
91-438 \\
13\end{array}$ & $\begin{array}{c}96 \\
78 \\
22-238 \\
7\end{array}$ \\
\hline \multirow[t]{4}{*}{ Coquimbo } & Summer & Coast & $\begin{array}{l}\text { Avg } \\
\text { SD } \\
\text { Range } \\
n\end{array}$ & $\begin{array}{c}1264 \\
656 \\
605-2224 \\
5\end{array}$ & $\begin{array}{c}294 \\
160 \\
90-639 \\
13\end{array}$ & & & $\begin{array}{c}34 \\
19 \\
13-64 \\
5\end{array}$ \\
\hline & & Ocean & $\begin{array}{l}\text { Avg } \\
\text { SD } \\
\text { Range } \\
n\end{array}$ & $\begin{array}{c}425 \\
46 \\
392-457 \\
2\end{array}$ & $\begin{array}{c}145 \\
36 \\
110-182 \\
3\end{array}$ & & & $\begin{array}{c}34 \\
8 \\
28-40 \\
2\end{array}$ \\
\hline & Winter & Coast & $\begin{array}{l}\text { Avg } \\
\text { SD } \\
\text { Range } \\
\mathrm{n}\end{array}$ & $\begin{array}{c}807 \\
290 \\
602-1012 \\
2\end{array}$ & $\begin{array}{c}77 \\
56 \\
34-173 \\
5\end{array}$ & & & $\begin{array}{c}16 \\
18 \\
3-29 \\
2\end{array}$ \\
\hline & & Ocean & $\begin{array}{l}\text { Avg } \\
\text { SD } \\
\text { Range } \\
n\end{array}$ & $\begin{array}{c}1034 \\
897 \\
399-1668 \\
2\end{array}$ & $\begin{array}{c}109 \\
39 \\
66-144 \\
39\end{array}$ & & & $\begin{array}{c}3 \\
15 \\
9-29 \\
2\end{array}$ \\
\hline \multirow[t]{4}{*}{ Concepción } & Spring & Coast & $\begin{array}{l}\text { Avg } \\
\text { SD } \\
\text { Range } \\
\mathrm{n}\end{array}$ & $\begin{array}{c}4540 \\
2531 \\
1200-8740 \\
6\end{array}$ & $\begin{array}{c}421 \\
196 \\
239-760 \\
7\end{array}$ & $\begin{array}{c}22.7 \\
16.2 \\
12.7-58.8 \\
7\end{array}$ & $\begin{array}{c}621 \\
444 \\
348-1612 \\
7\end{array}$ & $\begin{array}{c}11 \\
7 \\
4-22 \\
6\end{array}$ \\
\hline & & Ocean & $\begin{array}{l}\text { Avg } \\
\text { SD } \\
\text { Range } \\
n\end{array}$ & $\begin{array}{c}430 \\
156 \\
320-540 \\
2\end{array}$ & $\begin{array}{c}97 \\
8 \\
93-102 \\
2\end{array}$ & $\begin{array}{c}20.9 \\
2.4 \\
19.2-22.6 \\
2\end{array}$ & $\begin{array}{c}573 \\
65 \\
527-618 \\
2\end{array}$ & $\begin{array}{c}24 \\
7 \\
19-29 \\
2\end{array}$ \\
\hline & Winter & Coast & $\begin{array}{l}\text { Avg } \\
\text { SD } \\
\text { Range } \\
\mathrm{n}\end{array}$ & $\begin{array}{c}874 \\
477 \\
481-1710 \\
6\end{array}$ & $\begin{array}{c}70 \\
8 \\
63-80 \\
6\end{array}$ & $\begin{array}{c}57.7 \\
9.6 \\
48.3-71.4 \\
6\end{array}$ & $\begin{array}{c}1274 \\
211 \\
1067-1579 \\
10\end{array}$ & $\begin{array}{c}10 \\
4 \\
5-14 \\
6\end{array}$ \\
\hline & & Ocean & $\begin{array}{l}\text { Avg } \\
\text { SD } \\
\text { Range } \\
\mathrm{n}\end{array}$ & $\begin{array}{c}573 \\
253 \\
415-865 \\
3\end{array}$ & $\begin{array}{c}97 \\
19 \\
75-111 \\
3\end{array}$ & $\begin{array}{c}44.7 \\
14.2 \\
35.9-61.1 \\
3\end{array}$ & $\begin{array}{c}733 \\
233 \\
589-1002 \\
3\end{array}$ & $\begin{array}{c}19 \\
8 \\
12-27 \\
3\end{array}$ \\
\hline
\end{tabular}

\section{Winter (El Niño)}

The July 1997 Antofagasta upwelling cruise took place during the strong 1997/1998 El Niño event, which in all probability enhanced the expected seasonal drop in productivity of this system. This was evi- denced by a decrease by an approximate factor of 5 in PP during the winter cruise at the inshore stations $\left(1215 \pm 1594 \mathrm{mg} \mathrm{C} \mathrm{m}^{-2} \mathrm{~d}^{-1}, \mathrm{n}=7\right.$, range 23 to $3800 \mathrm{mgC}$ $\mathrm{m}^{-2} \mathrm{~d}^{-1}$ ) compared to the summer cruise. This drop in PP was not, however, observed offshore, where the $\mathrm{PP}$ values $\left(848 \pm 628 \mathrm{mg} \mathrm{C} \mathrm{m}^{-2} \mathrm{~d}^{-1}, \mathrm{n}=7\right.$, range 122 to 
$1799 \mathrm{mgC} \mathrm{m}^{-2} \mathrm{~d}^{-1}$ ) were similar to those measured during the summer cruise (Table 3). The drop in the overall productivity of the Antofagasta upwelling ecosystem was also reflected in an almost 4-fold decrease in the daily average inshore BSP (490 \pm $178 \mathrm{mgC} \mathrm{m}^{-2} \mathrm{~d}^{-1}, \mathrm{n}=16$, range 291 to $867 \mathrm{mgC} \mathrm{m}^{-2}$ $\mathrm{d}^{-1}$ ) and an almost 2-fold decrease in the daily average offshore BSP $\left(450 \pm 267 \mathrm{mg} \mathrm{C} \mathrm{m}^{-2} \mathrm{~d}^{-1}, \mathrm{n}=13\right.$, range 243 to $1144 \mathrm{mg} \mathrm{C} \mathrm{m}^{-2} \mathrm{~d}^{-1}$ ). Inshore, the average BA was $9.6 \pm 4.4 \times 10^{9}$ cells $\mathrm{m}^{-2}(\mathrm{n}=16$, range 3.8 to $19.9 \times$ $10^{9}$ cells m${ }^{-2}$ ), while offshore it was $7.4 \pm 2.6 \times 10^{9}$ cells $\mathrm{m}^{-2}\left(\mathrm{n}=13\right.$, range 2.5 to $10.7 \times 10^{9}$ cells $\left.\mathrm{m}^{-2}\right)$. Inshore BOC averaged $391 \pm 178 \mathrm{mgC} \mathrm{m}^{-2}(\mathrm{n}=16$, range 157 to $815 \mathrm{mg} \mathrm{C} \mathrm{m}^{-2}$ ), while offshore the average BOC was $262 \pm 136 \mathrm{mg} \mathrm{C} \mathrm{m}^{-2}$ ( $\mathrm{n}=13$, range 91 to $438 \mathrm{mg} \mathrm{C} \mathrm{m}^{-2}$ ). The average BSP/PP inshore was $478 \pm 726 \%$ (n= 7, 18 to $1811 \%$ ). The high variance of the inshore BSP/PP can be attributed to 2 stations with high bacterial production and low PP. Were the data from these stations to be excluded, the average BSP/PP would be $67 \pm$ $55 \%$. Offshore, the average BSP as percentage PP was $96 \pm 78 \%(\mathrm{n}=7$, range 22 to $238 \%$ ).

\section{Coquimbo upwelling ecosystem}

\section{Summer (non-El Niño)}

The Coquimbo upwelling ecosystem is an oligotrophic area of persistent upwelling. This is reflected in the low average $\mathrm{PP}$ values measured at the inshore stations $\left(1264 \pm 656 \mathrm{mg} \mathrm{C} \mathrm{m}^{-2} \mathrm{~d}^{-1}, \mathrm{n}=5\right.$, range 605 to $2224 \mathrm{mg} \mathrm{C}$ $\mathrm{m}^{-2} \mathrm{~d}^{-1}$ ) (Table 3). Offshore, the average PP was $425 \pm$ $46 \mathrm{mg} \mathrm{C} \mathrm{m}^{-2} \mathrm{~d}^{-1}$ ( $\mathrm{n}=2$, range 392 to $457 \mathrm{mg} \mathrm{C} \mathrm{m}^{-2} \mathrm{~d}^{-1}$ ). The oligotrophic conditions of Coquimbo were also reflected in the low levels of BSP measured both inshore $\left(294 \pm 160 \mathrm{mg} \mathrm{C} \mathrm{m}^{-2} \mathrm{~d}^{-1}, \mathrm{n}=13\right.$, range 90 to $639 \mathrm{mg} \mathrm{C} \mathrm{m}^{-2}$ $\left.\mathrm{d}^{-1}\right)$ and offshore $\left(145 \pm 36 \mathrm{mg} \mathrm{C} \mathrm{m}^{-2} \mathrm{~d}^{-1}, \mathrm{n}=3\right.$, range 110 to $182 \mathrm{mg} \mathrm{C} \mathrm{m}^{-2} \mathrm{~d}^{-1}$ ). Inshore, the average BSP/PP was $34 \pm 19 \%$ ( $\mathrm{n}=5$, range 13 to $64 \%$ ), while at the offshore stations it was $34 \pm 8 \%(n=2$, range 28 to $40 \%)$.

\section{Winter (non-El Niño)}

The lowest inshore values of PP were measured during winter cruises to the Coquimbo upwelling area $\left(807 \pm 290 \mathrm{mg} \mathrm{C} \mathrm{m}^{-2} \mathrm{~d}^{-1}, \mathrm{n}=2\right.$, range 602 to $1012 \mathrm{mg} \mathrm{C}$ $\mathrm{m}^{-2} \mathrm{~d}^{-1}$ ) (Table 3). At the offshore stations the daily average PP was $1034 \pm 897 \mathrm{mgC} \mathrm{m}^{-2} \mathrm{~d}^{-1}(\mathrm{n}=2$, range 399 to $1668 \mathrm{mg} \mathrm{C} \mathrm{m}^{-2} \mathrm{~d}^{-1}$ ). During the winter cruises the BSP also reached its lowest values in the Coquimbo area, both inshore $\left(77 \pm 56 \mathrm{mgC} \mathrm{m}^{-2} \mathrm{~d}^{-1}, \mathrm{n}=5\right.$, range 34 to $\left.173 \mathrm{mg} \mathrm{C} \mathrm{m}^{-2} \mathrm{~d}^{-1}\right)$ and offshore $\left(109 \pm 39 \mathrm{mg} \mathrm{C} \mathrm{m}^{-2}\right.$ $\mathrm{d}^{-1}, \mathrm{n}=3$, range 66 to $144 \mathrm{mg} \mathrm{C} \mathrm{m}^{-2} \mathrm{~d}^{-1}$ ). The average
$\mathrm{BSP} / \mathrm{PP}$ measured at the inshore stations was $16 \pm 18 \%$ ( $\mathrm{n}=2$, range 3 to $29 \%$ ) while at the offshore stations it was $19 \pm 15 \%(\mathrm{n}=2$, range 9 to $29 \%)$.

\section{Concepción upwelling ecosystem}

$$
\text { Spring (non-El Niño) }
$$

The Concepción upwelling ecosystem comprises the widest continental shelf $(40 \mathrm{~km})$ in the HCS off Chile, and is an area known for its high productivity. This area was visited during a 2 wk long cruise in October 1998 (austral spring) under intense, wind-driven upwelling conditions. The daily average PP measured at the inshore stations in the Concepción upwelling ecosystem during this study was $4540 \pm 2531 \mathrm{mg} \mathrm{C} \mathrm{m}^{-2}$ $\mathrm{d}^{-1}\left(\mathrm{n}=6\right.$, range 1200 to $\left.8740 \mathrm{mg} \mathrm{C} \mathrm{m}^{-2} \mathrm{~d}^{-1}\right)$, while offshore it decreased by an order of magnitude (430 \pm $156 \mathrm{mg} \mathrm{C} \mathrm{m}^{-2} \mathrm{~d}^{-1}, \mathrm{n}=2$, range 320 to $540 \mathrm{mg} \mathrm{C} \mathrm{m}^{-2} \mathrm{~d}^{-1}$ ) (Table 3 ). The daily average BSP measured at the inshore stations was $421 \pm 196 \mathrm{mg} \mathrm{C} \mathrm{m}^{-2} \mathrm{~d}^{-1}(\mathrm{n}=7$, range 239 to $760 \mathrm{mgC} \mathrm{m}^{-2} \mathrm{~d}^{-1}$ ), while offshore the average BSP decreased by a factor of $4\left(97 \pm 8 \mathrm{mgC} \mathrm{m}^{-2} \mathrm{~d}^{-1}\right.$, $\mathrm{n}=2$, range 93 to $102 \mathrm{mgC} \mathrm{m}^{-2} \mathrm{~d}^{-1}$ ). Inshore, the average BA was $22.7 \pm 16.2 \times 10^{9}$ cells $\mathrm{m}^{-2}(\mathrm{n}=7$, range 12.7 to $58.8 \times 10^{9}$ cells m${ }^{-2}$ ), while offshore it was $20.9 \pm 2.4 \times$ $10^{9}$ cells $\mathrm{m}^{-2}\left(\mathrm{n}=2\right.$, range 19.2 to $22.6 \times 10^{9}$ cells m$\left.^{-2}\right)$. BOC inshore averaged $621 \pm 444 \mathrm{mg} \mathrm{C} \mathrm{m}^{-2} \mathrm{~d}^{-1}(\mathrm{n}=7$, range 348 to $1612 \mathrm{mgC} \mathrm{m}^{-2} \mathrm{~d}^{-1}$ ), while offshore the average BOC was $573 \pm 65 \mathrm{mg} \mathrm{C} \mathrm{m}^{-2} \mathrm{~d}^{-1}$ ( $\mathrm{n}=2$, range 527 to $618 \mathrm{mg} \mathrm{C} \mathrm{m}^{-2} \mathrm{~d}^{-1}$ ) (Table 3). Inshore the average $\mathrm{BSP} / \mathrm{PP}$ was $11 \pm 7 \%(\mathrm{n}=6$, range 4 to $22 \%$ ) while offshore it was $24 \pm 7 \%$ ( $n=2$, range 19 to $29 \%$ ).

\section{Winter (non-El Niño)}

During the winter, upwelling favourable wind events in the Concepción area show a marked decline. This, coupled with a reduction in the light field, results in a seasonal drop in the productivity of the area. This condition was reflected in the average PP at the inshore stations which, during the winter cruise, showed a 5-fold drop (874 $\pm 477 \mathrm{mg} \mathrm{C} \mathrm{m}^{-2} \mathrm{~d}^{-1}, \mathrm{n}=6$, range 481 to $1710 \mathrm{mg} \mathrm{C} \mathrm{m}^{-2} \mathrm{~d}^{-1}$ ) compared to the values measured in October (Table 3). Offshore, however, the average $\mathrm{PP}$ values were similar $\left(573 \pm 253 \mathrm{mg} \mathrm{C} \mathrm{m}^{-2} \mathrm{~d}^{-1}, \mathrm{n}=3\right.$, range 415 to $865 \mathrm{mg} \mathrm{C} \mathrm{m}^{-2} \mathrm{~d}^{-1}$ ) to those measured during the October cruise. The seasonal drop in the productivity of the system was also reflected in the BSP values, which inshore showed a 6-fold decrease $70 \pm$ $8 \mathrm{mg} \mathrm{C} \mathrm{m}^{-2} \mathrm{~d}^{-1}, \mathrm{n}=6$, range 63 to $80 \mathrm{mgC} \mathrm{m}^{-2} \mathrm{~d}^{-1}$ ). Offshore, the average BSP was similar to the BSP measured during the spring season $\left(97 \pm 19 \mathrm{mg} \mathrm{C} \mathrm{m}^{-2} \mathrm{~d}^{-1}\right.$, 
Table 4. Bacterial secondary production $\left(\mathrm{mgC} \mathrm{m}^{-2} \mathrm{~d}^{-1}\right)$. Kruskal-Wallis ANOVA by rank $(H)$ comparing latitudinal (Antofagasta, Coquimbo and Concepción upwelling ecosystems), seasonal (spring/summer upwelling and winter non-upwelling) and coast-offshore differences. ${ }^{*}$ Significant difference, $\mathrm{n}=$ no. of samples

\begin{tabular}{|lrrrl|}
\hline Parameter & $H$ & $\mathrm{n}$ & $\mathrm{df}$ & $\mathrm{p}$ \\
\hline Latitude & 26.8 & 96 & 2 & $<0.001^{*}$ \\
Antofagasta & & & & \\
$\quad$ Season & 21.5 & 55 & 1 & $<0.001^{*}$ \\
$\quad$ Summer: inshore-offshore & 0.5 & 26 & 1 & $>0.1^{*}$ \\
$\quad$ Winter: distance-offshore & 3.8 & 29 & 1 & $<0.05^{*}$ \\
Coquimbo & & & & \\
$\quad$ Season & 11.3 & 23 & 1 & $<0.001^{*}$ \\
$\quad$ Summer: inshore-offshore & 0.06 & 17 & 1 & $>0.1$ \\
$\quad$ Winter: inshore-offshore & 1.9 & 6 & 1 & $>0.1$ \\
Concepción & & & & \\
$\quad$ Season & 10.4 & 18 & 1 & $<0.001^{*}$ \\
$\quad$ Summer: inshore-offshore & 4.2 & 9 & 1 & $<0.05^{*}$ \\
$\quad$ Winter: inshore-offshore & 3.3 & 9 & 1 & $>0.05$ \\
& & & & \\
\hline
\end{tabular}

$\mathrm{n}=3$, range 75 to $111 \mathrm{mgC} \mathrm{m} \mathrm{m}^{-2}$ ). Inshore, the average $\mathrm{BA}$ was $57.7 \pm 9.6 \times 10^{9}$ cells $\mathrm{m}^{-2}(\mathrm{n}=6$, range 48.3 to $71.4 \times 10^{9}$ cells $\mathrm{m}^{-2}$ ), while offshore it was $44.7 \pm$ $14.2 \times 10^{9}$ cells m$^{-2}\left(\mathrm{n}=3\right.$, range 35.9 to $61.1 \times 10^{9}$ cells $\mathrm{m}^{-2}$ ). Inshore, the average BOC was $1274 \pm 211 \mathrm{mgC}$ $\mathrm{m}^{-2} \mathrm{~d}^{-1}$ ( $\mathrm{n}=6$, range 1067 to $1579 \mathrm{mg} \mathrm{C} \mathrm{m}^{-2} \mathrm{~d}^{-1}$ ) while offshore it was $733 \pm 233 \mathrm{mgC} \mathrm{m}^{-2} \mathrm{~d}^{-1}$ ( $\mathrm{n}=3$, range 589 to $1002 \mathrm{mg} \mathrm{C} \mathrm{m}^{-2} \mathrm{~d}^{-1}$ ). The average BSP/PP inshore

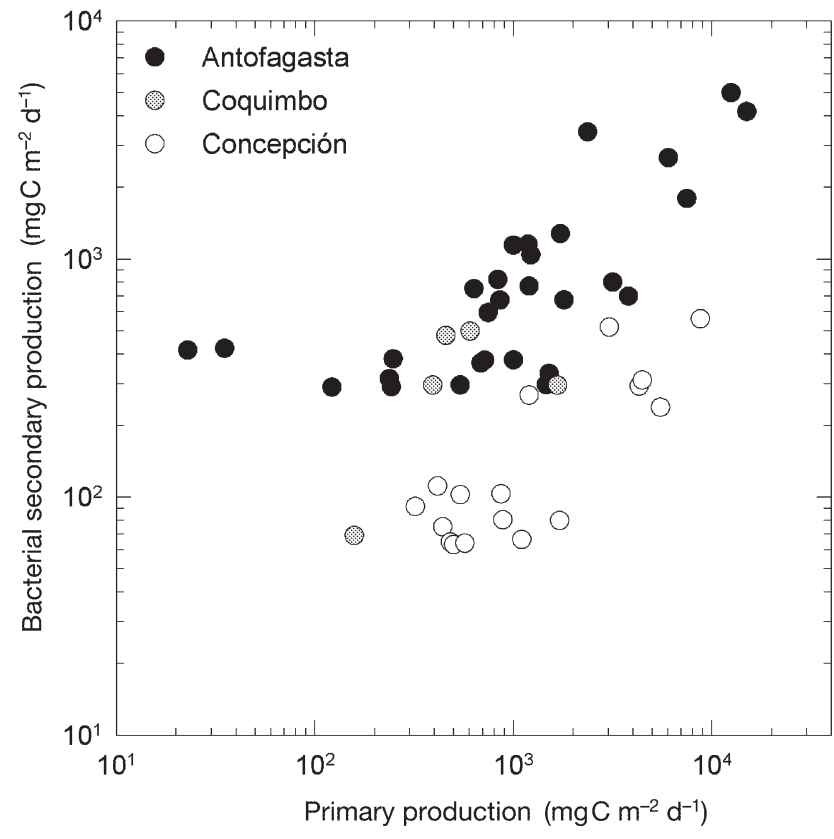

Fig. 2. Primary production versus bacterial secondary production. Integrated data from Antofagasta, Coquimbo and Concepción upwelling systems and adjacent oceanic areas (log-log scale)

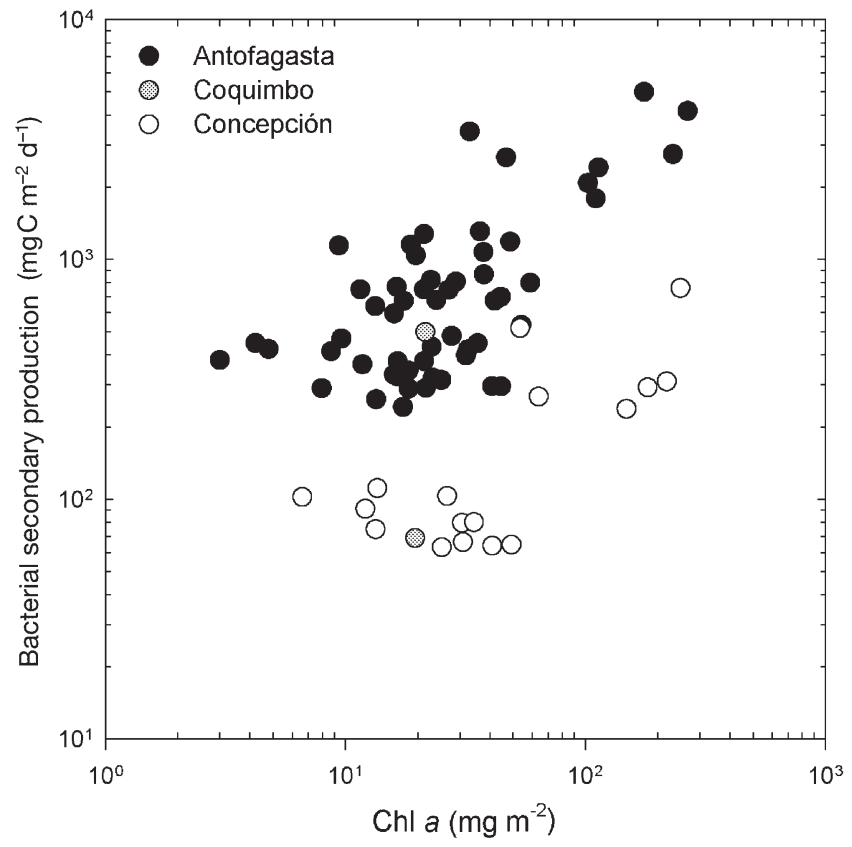

Fig. 3. Chl a versus bacterial secondary production. Integrated data from Antofagasta, Coquimbo and Concepción upwelling systems and adjacent oceanic areas (log-log scale)

was $10 \pm 4 \%(\mathrm{n}=6$, range 5 to $14 \%)$, while offshore it was $19 \pm 8 \%(\mathrm{n}=3$, range 12 to $27 \%)$.

Results of a Kruskal-Wallis ANOVA by ranks $(H)$ comparing latitudinal (Antofagasta, Coquimbo and Concepción upwelling ecosystems), seasonal (spring/ summer upwelling and winter non-upwelling) and coast-offshore differences in BSP are shown in Table 4. Significant differences in BSP were found between the 3 study areas $(H=26.8, \mathrm{p}<0.001)$. Within the Antofagasta data set there was a significant difference $(H=$ 21.5, $\mathrm{p}<0.001$ ) between the summer and winter cruises, but significant difference between inshore and offshore stations were only found during the winter (summer: $H=0.5, \mathrm{p}>0.1$; winter: $H=3.8$, $\mathrm{p}<0.05$ ). In Coquimbo, the BSP also showed significant seasonal differences $(H=11.3, \mathrm{p}<0.001)$, but no significant differences were detected between inshore and offshore stations (summer: $H=0.06, \mathrm{p}>0.1$; winter: $H=1.9, \mathrm{p}>$ 0.1). In Concepción there were significant differences between the spring and winter cruises $(H=10.4$, $p<$ 0.001). Significant differences between inshore and offshore stations were detected during the spring $(H=$ $4.2, \mathrm{p}<0.05)$, but not in winter $(H=3.3, \mathrm{p}>0.05)$.

\section{PP, BSP, BOC, and chl a}

Integrated water-column BSP values from Antofagasta, Coquimbo and Concepción, were correlated 


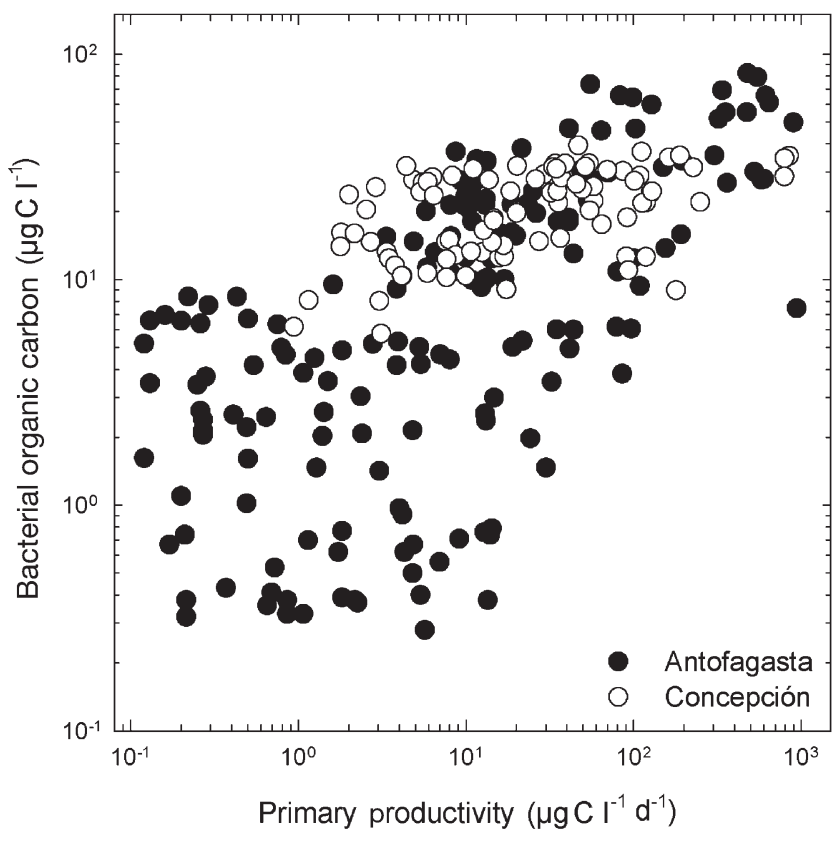

Fig. 4. Primary production versus bacterial organic carbon. Discrete data from Antofagasta and Concepción upwelling systems and adjacent oceanic areas (log-log scale)

with integrated water-column PP and chl a. A significant positive relationship was found between integrated PP and integrated BSP $\left(\mathrm{r}^{2}=0.57, \mathrm{p}<0.05, \mathrm{n}=\right.$ 51, $y=0.25 x+186.26$ ) (Fig. 2). The correlation between integrated chl $a$ and integrated BSP was lower, but still significant $\left(\mathrm{r}^{2}=0.28, \mathrm{p}<0.05, \mathrm{n}=74, y=8.29 x\right.$ +374.6 ) (Fig. 3). The correlation between discrete PP and BOC and between discrete chl $a$ and BOC values was also significant $\left(\mathrm{r}^{2}=0.25, \mathrm{p}<0.05, \mathrm{n}=270, y=\right.$ $0.05 x+13.89)$ and $\left(\mathrm{r}^{2}=0.19, \mathrm{p}<0.05, \mathrm{n}=427, y=1.63 x\right.$ +13.18 ), respectively (Figs. 4 \& 5). The correlation between discrete temperature and both discrete BSP and discrete BOC values was not significant $\left(\mathrm{r}^{2}=0.0\right.$, $\mathrm{p}>0.05, \mathrm{n}=420$ and $\left.\mathrm{r}^{2}=0.04, \mathrm{p}>0.05, \mathrm{n}=420\right)$, respectively (Figs. $6 \& 7$ ).

\section{DISCUSSION}

The data show that bacteria are an important component of the pelagic planktonic community in upwelling ecosystems in the HCS off Chile. With the exception of the values measured in the Coquimbo upwelling system, the upper values of BSP reported in this study are higher than any reported in the literature for a variety of marine environments (Brown et al. 1991, Kirchman et al. 1995, Lochte et al. 1997, Wiebinga et al. 1997, Pomroy \& Joint 1999, Shiah et al. 2000). This was also apparent in the case of discrete values of BSP (data not shown in this study) (Fuhrman et al. 1980, Coffin \& Sharp 1987, McManus \& Peterson 1988, Sherry et al. 1999). The highest value of 4999 $\mathrm{mgC} \mathrm{m} \mathrm{m}^{-2} \mathrm{~d}^{-1}$ measured in Antofagasta is possibly the highest value of BSP ever reported in the literature. This result was not unexpected, as the HCS constitutes

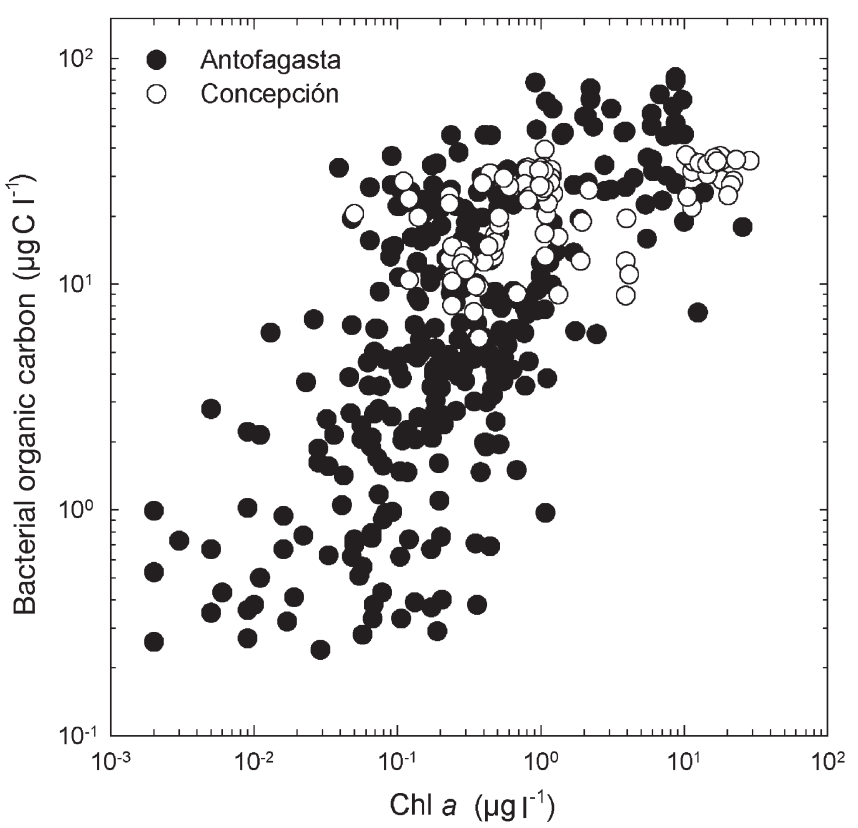

Fig. 5. Chl a versus bacterial organic carbon. Discrete data from Antofagasta and Concepción upwelling systems and adjacent oceanic areas (log-log scale)

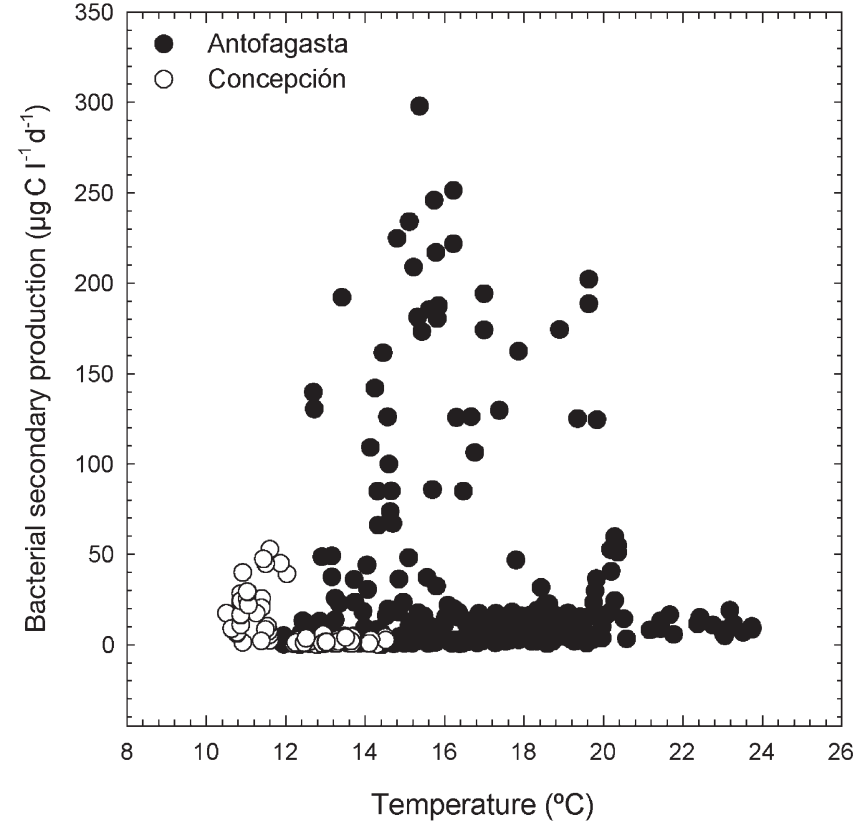

Fig. 6. Temperature versus bacterial secondary production. Discrete data from Antofagasta and Concepción upwelling systems and adjacent oceanic areas 


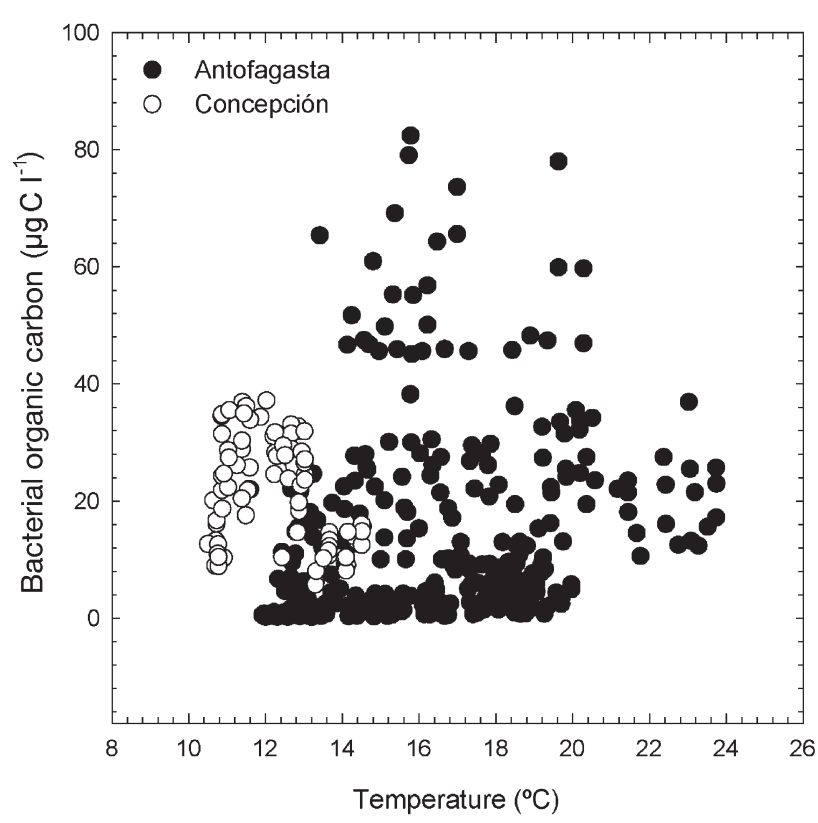

Fig. 7. Temperature versus bacterial organic carbon. Discrete data from Antofagasta and Concepción upwelling systems and adjacent oceanic areas

one of the most productive large marine ecosystems, and is consistent with the fact that the highest values of PP have been reported in the area (Daneri et al. 2000).

The data also showed significant latitudinal differences in the levels of bacterial activity. Highest BSP values were measured in the Antofagasta upwelling area during the January 1997 cruise, while the lowest BSP values were recorded in the Coquimbo upwelling area. During January 1997 the Antofagasta upwelling area suffered an anomalous decrease in winds, favouring upwelling, which almost certainly prevented the area from attaining its full productivity potential. It is possible therefore that bacterial activity in the Antofagasta area could potentially be higher. However, it is also possible that the more quiescent upwelling conditions that characterised the pre-El Niño period stimulated higher levels of bacteria activity than usual. The pre-El Niño (low upwelling activity) conditions found in Antofagasta contrast with the situation observed during the summer cruise to the Concepción upwelling area which was subjected to active upwelling and wind-stress conditions that were 2 standard deviations greater than the climatological mean (D. Figueroa pers. comm.). High wind stress induces mixing in the water column which, to a certain extent, restricts biological productivity. It is thus possible that bacteria can reach higher levels of activity in the Concepción upwelling area. The only published BSP data reported for the Concepción upwelling area, and indeed, for the whole HCS, indicates that the highest levels of BSP are attained in the area during periods of calm postupwelling conditions (McManus \& Peterson 1988). Our discrete BSP values measured in Concepción were a factor of 2 higher than the values reported by McManus \& Peterson (1988). A possible explanation for this difference may be related to our use of an empirical bacterial cellular carbon average of $27.4 \mathrm{fgC}$ for the Concepción upwelling while McManus \& Peterson (1988) relied on a fixed, literature-based value of $20 \mathrm{fg}$ C. Of the 3 upwelling areas sampled, Coquimbo showed a consistently lower bacterial activity despite the fact that the area was only visited during years considered oceanographically as 'normal' that is nonEl-Niño or La Niña years. This low bacterial activity in the Coquimbo area is in agreement with observations that Coquimbo has been oceanographically described as an oligotrophic permanent upwelling area with productivity values that are consistently lower than PP values observed in other upwelling centres within the HCS off Chile (Daneri et al. 2000).

Important seasonal differences in bacterial activity were also observed in the 3 sites visited. Highest levels of BSP were measured during the spring and summer cruises. Wind-driven upwelling events in the HCS are more prominent during the spring, summer and early austral fall months. During the winter, a weakening of the Pacific anticyclone coupled with a reduced light field results in a decrease in the productivity of the system. This was reflected in lower overall PP values, which showed a 2- to 5-fold decrease during the winter at the 3 study sites. This seasonal drop in the observed PP was also reflected in the BSP values which, in the case of Antofagasta and Coquimbo at the inshore stations, showed a near 4 -fold decrease, while in the Concepción samples an almost 6-fold decrease was noted. This more pronounced decrease in BSP in Concepción may reflect the more marked seasonality in the productivity cycles in this upwelling area (Daneri et al. 2000). A strict seasonal comparison with the Antofagasta upwelling is, however, not possible since the Antofagasta upwelling area was visited during July 1998 when the region was under the influence of the particularly strong 1997-98 El-Niño event.

Although the dynamic nature of the HCS makes the setting of ecosystem boundaries difficult, important inshore-offshore differences were found during this study, in agreement with similar differences reported by Fuhrman et al. (1980) for the Southern California Bight. The main inshore-offshore differences were found in the Antofagasta and Concepción upwelling areas during the summer and spring cruises, respectively. This is consistent with inshore-offshore differences found in the levels of PP, although the decrease in BSP was not as pronounced as the decrease in PP. 
The average PP measured inshore in the Antofagasta upwelling area was 5 times greater than the offshore $\mathrm{PP}$, while for Concepción comparable offshore values were an order of magnitude lower than inshore PP values. The BSP values on the other hand showed a 2-fold drop at the inshore stations, while offshore they fell by a factor of 4 in the Antofagasta and Concepción upwelling ecosystems. In general, under more oligotrophic conditions such as those encountered during the winter cruises or during the cruises to the Coquimbo upwelling area, the coast-to-offshore gradient was less pronounced. As expected, the variance of the BSP data was greater inshore while the more oceanic stations showed lower variance. The less variable BSP values measured for the offshore stations reflect more homogeneous oceanographic conditions and probably represent accurate estimates of overall levels of bacterial activity within the more oceanic realm of the HCS off Chile.

The close coupling observed between PP levels and BSP during this study resulted in highly significant correlations between PP and BSP. The correlation of integrated PP and BSP was higher than the correlation of discrete PP and BSP values (data not presented in this study), thus supporting the view that a tighter coupling between bacteria activity and PP is obtained when analysing integrated data (Williams 1998). The strong correlation between PP and BSP reflects a tight coupling between carbon synthesis and bacterial consumption, confirming a very dynamic relationship between algal production and bacterial activity in the HCS. The correlation between chl a and BOC was significant, but not as high as that reported in a number of studies which have a shown strong correlation between bacterial abundance and chlorophyll in coastal environments (Fuhrman et al. 1980), including upwelling regions (Linley et al. 1983). Interestingly, the correlation between PP and BOC (a flux and a standing stock measurement) was better than the correlation between BOC and chl a (both standing stock measurements). During this study no significant correlation between BSP and BOC and temperature was found. This finding contradicts the data of Coffin \& Sharp (1987), who found a significant correlation between bacterial abundance and temperature, and of other studies that have shown temperature to be a more critical factor than substrate availability in controlling bacterial activity (Vootamen 1980, Wilson \& Stevenson 1980, Wright \& Coffin 1983, Coffin 1986). The high correlation between PP and BSP, coupled with the lack of correlation between temperature and BSP, would indicate that, in the HCS, substrate availability seems to be more important than temperature in limiting bacterial activity and abundance.
The results of this study indicate that an important fraction of the organic matter produced by phytoplankton activity is being channelled through the bacteria in the HCS off Chile. Taken as a percentage of PP, the data from the 3 upwelling areas sampled during this study showed that a significant proportion of PP was utilised by bacteria (ca. 63 to $96 \%$ in Antofagasta, 16 to $34 \%$ in Coquimbo and 10 to $24 \%$ in Concepción). Assuming a conservative bacterial growth yield of 0.25 (Daneri et al. 1994), the overall carbon utilisation by bacteria seems to be around or in excess of the in situ PP. These results are in agreement with data reported for other upwelling systems (Brown et al.1991, Ducklow 1993, Wiebinga et al. 1997) and for the Concepción shelf upwelling area (McManus \& Peterson 1988), and confirm the view that bacteria are an important component of upwelling ecosystems, and are capable of processing an important fraction of the organic carbon fixed by algal activity.

Acknowledgements. The professional assistance of the 'Abate Molina' crew is gratefully acknowledged. This research was funded by JGOFS/SIDA-SAREC/CONICYT, Project Sectorial Antofagasta FONDECYT 596002/CONICYT and FONDAP No. 150100007 . The chl a data were kindly supplied by Dr. Carmen Morales.

\section{LITERATURE CITED}

Andrews P, Williams PJleB (1971) Heterotrophic utilisation of dissolved organic compounds in the sea. III. Measurement of the oxidation rates and concentrations of glucose and amino acids in seawater. J Mar Biol Assoc UK 51:111-125

Azam F, Fenchel T, Field JG, Gray JS, Meyer-Reil LA, Thingstad F (1983) The ecological role of water-column microbes in the sea. Mar Ecol Prog Ser 10:257-263

Brown PC, Painting SJ, Cochrane KL (1991) Estimates of phytoplankton and bacterial biomass and production in the northern and southern Benguela ecosystems. S Afr J Mar Sci 11:537-564

Cho BC, Azam F (1990) Biogeochemical significance of bacterial biomass in the ocean's euphotic zone. Mar Ecol Prog Ser 63:253-259

Coffin RB (1986) Bacterial dynamics in response to phytoplankton, heterotrophic microflagellates and amino acid pools in the Delaware Estuary. PhD thesis, University of Delaware, Newark

Coffin RB, Sharp JH (1987) Microbial trophodynamics in the Delaware Estuary. Mar Ecol Prog Ser 41:253-266

Daneri G, Riemann B, Williams PJleB (1994) In situ bacterial production and growth yield measured by thymidine, leucine and fractionated dark oxygen uptake. J Plankton Res 16:105-113

Daneri G, Dellarossa V, Quiñones R, Jacob B, Montero $P_{1}$ Ulloa O (2000) Primary production and community respiration in the Humboldt Current System off Chile and associated oceanic areas. Mar Ecol Prog Ser 197:41-49

Ducklow HW (1993) Bacterioplankton distributions and production in the northwestern Indian Ocean and Gulf of Oman, September, 1986. Deep-Sea Res 40:753-771

Field JG, Griffiths CL, Linley EA (1980) Upwelling in a near- 
shore marine ecosystem and its biological implications. Estuar Coast Mar Sci 11:133-150

Fry JC (1990) Direct methods and biomass estimation. Methods Microbiol 22:41-85

Fuhrman JA, Azam F (1982) Thymidine incorporation as a measure of heterotrophic bacterioplankton production in marine surface water: evaluation and field result. Mar Biol 66:109-120

Fuhrman JA, Ammerman JW, Azam F (1980) Bacterioplankton in the coastal euphotic zone: distribution, activity and possible relationships with phytoplankton. Mar Biol 60: 201-207

Gocke K, Hoppe HG, Bauerfeind T (1983) Investigations on the influence of coastal upwelling and polluted rivers on the microflora of the northeastern Atlantic off Portugal. II. Activity and biomass production of the bacterial population. Bot Mar 26:189-199

Hagström Å, Larsson U, Hörstedt P, Normark S (1979) Frequency of dividing cells, a new approach to the determination of bacterial growth rates in aquatic environments. Appl Environ Microbiol 37:805-812

Hanson RB, Alvarez-Ossorio MT, Cal R, Campos MJ, Roman M, Santiago G, Varela M, Yoder JA (1986) Plankton response following a spring upwelling event in the Ria de Arosa, Spain. Mar Ecol Prog Ser 32:101-113

Holm-Hansen O, Lorenzen CJ, Holmes RW, Strickland JDH (1965) Fluorometric determination of chlorophyll. J Cons Int Explor Mer 30:3-15

Iriarte JL, Pizarro G, Troncoso VA, Sobarzo M (2000) Primary production and bionass of size-fractionated phytoplankton off Antofagasta, Chile (23 to $24^{\circ} \mathrm{S}$ ) during pre-El Niño and El Niño 1997. J Mar Syst 26:37-51

Kirchman DL, Rich JH, Barber RT (1995) Biomass and biomass production of heterotrophic bacteria along $140^{\circ} \mathrm{W}$ in the equatorial Pacific: effect of temperature on the microbial loop. Deep-Sea Res 42:603-619

Linley EAS, Newell RC, Lucas MI (1983) Quantitative relationships between phytoplankton, bacteria and heterotrophic microflagellates in shelf waters. Mar Ecol Prog Ser $12: 77-89$

Lee SH, Fuhrman JA (1987) Relationships between biovolume and biomass of naturally derived marine bacterioplankton. Appl Environ Microbiol 53:1298-1303

Lochte K, Bjørnsen PK, Giesenhagen H, Weber A (1997) Bacterial standing stock and production and their relation to phytoplankton in the Southern Ocean. Deep-Sea Res 44: 321-340

McManus GB, Peterson WT (1988) Bacterioplankton production in the nearshore zone during upwelling off central Chile. Mar Ecol Prog Ser 43:11-17

Newell RC, Turley CM (1987) Carbon and nitrogen flow through pelagic microheterotrophic communities. S Afr J Mar Sci 5:717-734

Painting SJ, Lucas MI, Muir DG (1989) Fluctuations in heterotrophic bacterial community, structure, activity and production in response to development and decay of phytoplankton in a mesocosm. Mar Ecol Prog Ser 129:129-141

Painting SJ, Lucas MI, Peterson WT, Brown PC, Hutchings L, Mitchell-Innes BA (1993) Dynamics of bacterioplankton communities during the development of an upwelling plume in the southern Benguela. Mar Ecol Prog Ser 35: $35-53$

Pomroy A, Joint I (1999) Bacterioplankton activity in the sur- face waters of the Arabian Sea during and after the 1994 SW monsoon. Deep-Sea Res 46:767-794

Porter KG, Feig YS (1980) The use of DAPI for identifying and counting aquatic microflora. Limnol Oceanogr 25:943-948

Rheinheimer G, Schmaljohann R (1983) Investigations on the influence of coastal upwelling and polluted rivers on the microflora of the northeastern Atlantic off Portugal. I. Size and composition of the bacterial population. Bot Mar 26: $137-152$

Riemann B, Bell RT (1990) Advances in estimating bacterial biomass and growth in aquatic systems. Arch Hydrobiol 25:385-402

Ryther JH (1969) Photosynthesis and fish production in the sea. Science 166:72-76

Ryther JH, Menzel DW, Hulburt EM, Lorenzen CJ, Corwin N (1971) Production and utilization of organic matter in Perú coastal current. Investig Pesq 35:43-59

Sherry ND, Boyd PW, Sugimoto K, Harrison PJ (1999) Seasonal and spatial patterns of heterotrophic bacterial production, respiration, and biomass in the subarctic NE Pacific. Deep-Sea Res 46:2557-2578

Shiah F, Liu K, Kao S, Gong G (2000) The coupling of bacterial production and hydrography in the southern East China Sea: spatial patterns in spring and fall. Cont Shelf Res 20: 459-477

Sieburth JMcN, Johnson KM Burney CH, Lavoie DM (1977) Estimation of in situ rates of heterotrophy using diurnal changes in dissolved organic matter and growth rates of picoplankton in diffusion culture. Helgol Wiss Meeresunters 30:565-570

Simon M, Azam F (1989) Protein content and protein synthesis rates of planktonic marine bacteria. Mar Ecol Prog Ser 51:201-213

Vootamen P (1980) Factor analysis of the impact of the environment on microbial communities in the Tvarminne area, southern coast of Finland. Appl Environ Microbiol 40: $55-61$

Walsh JJ (1981) A carbon budget for overfishing off Perú. Nature 290:300-304

Watson SW (1978) Role of bacteria in an upwelling ecosystem. In: Boje R, Tomczak M (eds) Upwelling ecosystems. Springer-Verlag, New York, p 139-154

Watson SW, Novitsky TJ, Quinby HL, Valois FW (1977) Determination of bacterial number and biomass in the marine environment. Appl Environ Microbiol 33:940-946

Wicks RJ, Robarts RD (1987) The extraction and purification of DNA labelled with [methyl- ${ }^{3} \mathrm{H}$ ] thymidine in aquatic bacterial production studies. J Plankton Res 9:1159-1166

Wiebinga CJ, Veldhuis MJW, Baar HJW (1997) Abundance and productivity of bacterioplankton in relation to seasonal upwelling in the northwest Indian Ocean. Deep-Sea Res 44:451-476

Williams PJleB (1998) The balance of plankton respiration and photosynthesis in the open oceans. Nature 394:55-57

Wilson CA, Stevenson LH (1980) The dynamics of the bacterial population associated with a salt marsh. J Exp Mar Biol Ecol 48:123-138

Wright RT, Coffin RB (1983) Planktonic bacteria in estuaries and coastal waters of northern Massachusetts: spatial and temporal distribution. Mar Ecol Prog Ser 11:205-215

Zimmermann R, Bolter M, Wolter K (1980) Eco-bacteriological investigation in the NW African upwelling area. Bot Mar 23:179-191 